Volume 13

Number 12013

Article 6

December 2013

\title{
Genetic Engineering and the Pursuit of Human Perfection
}

\author{
K. C. Pugh \\ Cedarville University, kcpugh@cedarville.edu
}

DigitalCommons@Cedarville provides a publication platform for fully open access journals, which means that all articles are available on the Internet to all users immediately upon publication. However, the opinions and sentiments expressed by the authors of articles published in our journals do not necessarily indicate the endorsement or reflect the views of DigitalCommons@Cedarville, the Centennial Library, or Cedarville University and its employees. The authors are solely responsible for the content of their work. Please address questions to dc@cedarville.edu.

\section{Recommended Citation}

Pugh, K. C. (2013) "Genetic Engineering and the Pursuit of Human Perfection," CedarEthics: A Journal of Critical Thinking in Bioethics: Vol. 13 : No. 1 , Article 6. 


\title{
Genetic Engineering and the Pursuit of Human Perfection
}

Browse the contents of this issue of CedarEthics: A Journal of Critical Thinking in Bioethics.

\begin{abstract}
The idea of perfection has always captivated the attention of people across the ages. Whether in the form of gods, nature, or role models, people have always looked towards some form of the purest ideal. Perfection is not a novel idea by any means; however, it is only in recent years that human beings have actually sought to achieve it.
\end{abstract}

\section{Keywords}

Genetic engineering

\section{Creative Commons License}

\section{(ब) $\odot \Theta \Theta$}

This work is licensed under a Creative Commons Attribution-Noncommercial-No Derivative Works 3.0 License.

Follow this and additional works at: http:// digitalcommons.cedarville.edu/cedarethics

Part of the Bioethics and Medical Ethics Commons 


\title{
Genetic Engineering and the Pursuit of Human Perfection
}

\author{
K.C. Pugh \\ Cedarville University
}

\begin{abstract}
7 he idea of perfection has always captivated the attention of people across the ages. Whether in the form of gods, nature, or role models, people have always looked towards some form of the purest ideal. Perfection is not a novel idea by any means; however, it is only in recent years that human beings have actually sought to achieve it.
\end{abstract}

In the past, people viewed perfection as something outside the self, manifested in gods and nature. One might argue that Greek humanism was an exception; it is certainly apparent that the Greeks believed in the beauty and divinity of the human body. Though the Greeks often portrayed their ideal self throughout art and literature, they recognized perfection was not complete in them. In past history, perfection was strived for, but was not feasible.

The idea that perfection could never be achieved was seen as late as the middle of the nineteenth century with Nathaniel Hawthorne's short cautionary tale "The Birthmark." In this story, a scientist tries to perfect his wife by removing a crimson hand- shaped birthmark from her cheek. By doing so, she ends up dying, because otherwise she would be perfect. This echoes the idea that human perfection was truly unattainable (Zanger, 1983). This line of thinking changed drastically with the introduction of Darwinism several years later.

Darwinian evolution shook the world with its implications. Matter becoming progressively purified from imperfections would logically result in a more perfect human than a human in the past (Kimball, 2013). Perfection was no longer merely an ideal, but something that one could, and should, obtain. Medical Darwinism taught that some genotypes were inherently "greater" than others (Fischer, 2013), but this idea has led to some nasty complications. Some serious ethical questions remain in man's hunt for flawlessness: Is perfection really attainable? If it is, should we pursue it? If one were to pursue it, what implications would this have for ourselves, others, and the world around us?

The idea of achieving perfection is not just a theory in an abstract realm anymore. Recent technology has made human perfection seem more and more plausible, particularly at a physical level. Genetic engineering, a process that redefines the genome, can now be used to "correct" human flaws and perhaps even to supersede good characteristics and make them even better. This genetic engineering seems like a great prima facie good, but when examined deeper, may have many serious ethical pitfalls.

Using genetic engineering to reprogram humans into something that they are not provokes a sense of repugnance, and as Leon Kass says, there is great "wisdom in repugnance" (Kass, 2003). The idea of man playing God cause great concern for the type of love that human beings should exhibit towards one another (Sandel, 2004). This paper will address these ethical

CedarEthics, vol. 13, no. 1, pp. 27-33. ISSN 2333-9713

(C) 2013, K.C. Pugh, licensed under CC BY-NC-ND

(http://creativecommons.org/licenses/by-nc-nd/3.0/) 
questions by examining two sides of the issue. I will then present my own ethical analysis.

Our perspective on genetic engineering depends on the type of genetic engineering in question. There are four types of genetic engineering (Anderson, 1985). The first two are considered to be therapies. The first type, somatic cell therapy, "fixes" the body's somatic cells (all cells other than reproductive cells). This therefore relates just to one's own body. As an ethical matter, somatic cell gene therapy is not heavily debated, because it just impacts the individual, not future generations (Walters, 1997).

On the other hand, the second type, germ-line genetic therapy, raises more questions because it does impact future generations. Germ-line therapy "fixes" the sex cells (gametes), which would in turn "fix" future generations from possessing a gene with a negative trait. In other words, such therapy is inherited (Walters, 1997). This certainly seems like a good and noble thing to pursue. However, modern science can tell little about its adverse effects (Anderson, 1985). Although Anderson stated this nearly a decade ago, the problem remains.

The third form of genetic engineering is enhancement. Enhancement is different from the first two forms, because it involves modifying a gene that is not inherently wrong or debilitating. It may be debilitating in terms of cultural acceptance, but in terms of nature, the gene functions as it was intended to function. Enhancement is much more controversial than the first two types of genetic engineering. It operates through somatic cells, so it impacts just the individual (Anderson, 1985).

The fourth type of genetic engineering is so highly debated that it is not even seriously considered on a practical level, only theoretical. This is eugenic engineering and it involves not just "fixing" gametes, but enhancing them. This would essentially result in a recreation of a human being, and might potentially create a new type of "species" (Anderson, 1985).

This creation of a new line of humans clearly is of concern for people, including Michael Sandel, a bioethicist who opposes the pursuit of perfection. He fears the creation of two distinct classes of humans (Sandel, 2004). Although eugenic genetic engineering is likely to occur in the foreseeable future, it is still important to consider because of how it reflects on the attitudes of people towards the pursuit of perfection.

So is perfection a worthy goal to pursue? Some would argue that the pursuit of perfection should be avoided. Because of great evils that might result, it is better to avoid the matter altogether. Sandel, has said, "We live in a world where science moves faster than moral understanding" (2004, p. 51). Here he is using a well-known "slippery slope" argument. The slippery slope is the idea that allowing certain forms of genetic engineering will open the door for them all, since there is no clear cut distinction between therapy and enhancement. Without such a distinction, the pursuit of perfection could lead to disturbing consequences, potentially even resulting in two subspecies of human kind: the enhanced and the unenhanced. Considering the atrocities throughout history related in class conflict, this is a scary premise indeed.

Leon Kass argues that imperfection should not be seen as a hindrance, but something necessary for human flourishing. He argues against the pursuit of perfection by citing perfection as a 
source of great anxiety. He further claims that something feels eerily wrong about making humans perfect. This repugnance may come from the idea of man playing God, or may come from the idea that biotechnology would enable an improved nature to shine forth without teaching or training, an unnatural idea (2003, p. 15). Repugnance alone should cause us to avoid perfectionism.

Kass goes on to say that morality is necessary for living the fullest life possible: "I argue the pursuit of perfect bodies and further life-extension will deflect us from realizing more fully the aspirations to which our lives naturally point, from living well rather than merely staying alive" (p. 25). He would theoretically embrace therapy, but practically he believes the healing v. enhancement distinction to be of little value. Because of how nature operates, some will inevitably receive "the short end of the stick" due to the wide variation of natural gifts. No one is ever fully content with what they have.

When nature deals her cards, some receive only from the bottom of the deck. Conversely, it is often the most gifted and ambitious who most resent their limitations. Achilles was willing to destroy everything ... so little could he stomach that he was but a heel short of immortality (Kass, 2003, p. 14).

Kass most certainly acknowledges that we are not perfect, yet we should embrace this imperfection because it is what makes us human. It is what makes us live life in "rhythmed time," because perfection is merely a passing illusion.

I personally have mixed ideas about Kass's theories. There is certainly wisdom in repugnance: God has gifted man with conscience and a higher sense of understanding. However, Kass says that imperfection is good, which seems almost oxymoronic. Ultimately, perfection is what is good, and the only reason perfection is "bad" is because we live in a "bad" world, cursed by the fall of man. For example, Kass argues that aging is a necessary process of life essential for happiness. Yet, if we lived in a perfect world, aging would be a very terrible thing indeed. In a perfect world, an ageless body would be expected.

While Sandel and Kass might argue that perfection should be avoided, others consider the matter more positively, and claim that perfection would make the world a better place. The great philosopher Plato said in his Republic, "Whoever would act wisely would set the Idea of Good before him." In other words, pursuing what is best and optimal requires an ideal standard of what should be. Some argue that even in the pursuit of perfection, humans will never be perfect, thus claiming that all forms of genetic engineering are acceptable. Trachtman argues for this, claiming that even if life span is increased and certain genetic traits are "fixed," there will always be more problems to solve. He further agrees that the distinction between therapy and enhancement is too murky to define (2005).

Who determines what is acceptable for treatment and what is unacceptable? Trachtman worries that this will lead to discrimination, placing some infirmities or disabilities as somehow more serious than others. If we allow some forms of genetic engineering, then all should be allowed, in order to prevent discrimination (2005). 
Such a hierarchy of disabilities is dangerous, because many things can affect the pursuit of an average life. "Infirmities" may range from sickle-cell anemia to physical attractiveness. Indeed, physical attractiveness and gender both affect our functioning. Many argue that if we want all of us to have a normal life, genetic engineering must be available to all. Genetic enhancement is no longer "enhancement;" it enables one to live the most normal life possible. Such thinking would approve, not only of reconstructive surgery, but of aesthetic surgery as well. A positive perception by others is important to obtain "normal" functioning (Raniszewska-Wyrwa, 2013).

The autonomy of the individual is also important in the pursuit of the perfection. If an individual believes she would be better off a certain way, wouldn't it be within her rights to obtain that trait? Furthermore, many believe that parents should have the autonomy to determine the type of child they will raise. This might create a case for parents to use germ-line therapy or enhancement to ensure a "normal" child (Zimmerman, 1991).

If genetic enhancement can be used to prevent heart attacks, cancer, behavioral disorders, and the like, then it certainly seems that it would help both the parent and the child to make use of genetic engineering. We can assume that if a fetus were able to choose to be "normal" or not, it would undoubtedly choose to be "normal." In other medical practices, the parent has autonomy over the child. Why not in this practice, too?

I have mixed feelings on these ideas as well. While I agree that it would be beneficial to improve humans as much as possible, the practice of unfiltered genetic engineering could lead to horrid consequences. In addition, this practice operates on the principle of transforming love. While parents may want their child to be the very best, it would also be very upsetting for a child to discover that he was "not good enough," according to such external pressure.

Sandel thinks highly of both transforming and accepting love, accepting love being that unconditional love that is present in spite of the flaws of a person (2004). Research has shown that this accepting love is not merely a nice idea, but is essential for the proper psychological development of a child (Litovsky, 1985). By allowing all types of genetic engineering, perhaps such accepting love will disappear. There is a whole realm of such questions that may emerge when asking if cultural norms should define one's "normal" level of functioning.

So, the question remains: where does one draw the line? What forms of genetic engineering are ethically acceptable? Does it stop with somatic cell gene therapy? Or should perfection be pursued at all costs, making even eugenic genetic engineering appropriate?

Many draw the line at the distinction between "therapy" and "enhancement." Therapy restores one to her natural state, while enhancement clearly goes above and beyond natural capabilities. As Anderson notes, replacing a faulty part is different from trying to add something new to a normally functioning system (1985). While this distinction is logical in theory, it is much trickier in practice.

Paul Wolpe, an ethicist who specializes in brain function, does not underestimate the importance of this distinction. How do we really determine when one is "sick?" If someone is sick, then surely a healthcare provider should try to ameliorate her circumstances. But defining "sick" is 
easier said than done. "Health" and "sickness" are not black and white terms, but exist on a continuum. The slippery slope argument says that if somatic cell gene therapy is allowed, there is great potential for eugenic genetic enhancement, because "sickness" does not have a universal definition (Wolpe, 2002).

For example, shortness, while not a medical sickness, has been shown to have negative effects on men. Taller men are seen as more attractive and have higher reproductive rates, giving them a sort of advantage (Nettle, 2002). So while shortness is not an "illness," it could still be defined as a sickness to some because of its negative effects.

Because of this tricky predicament of the slippery slope, Wolpe stipulates a difference between obligatory and non-obligatory medical services. Society only has an obligation to provide therapy when one has departed from "normal" organization and functioning. Note that "normal" does not mean "average;" one can be below average yet still normal (2002).

I personally agree with Wolpe's definition of when therapy is acceptable. Although the slippery slope argument has some validity, if good regulations were set in place, one could define the difference between therapy and enhancement. The difference comes in when considering what is natural for a human. Enhancement is when a person is genetically modified in such a way that it becomes unnatural.

Because my view operates on the premise that there can be a distinction between therapy and enhancement, my belief does not lean one way or another, but rather moves toward the middle. As an idealist, I want to achieve the best world possible, by practicing a "transforming love." Yet as a compassionate person, I do not think achieving perfection is worth it if it decreases the intrinsic value of humans, or reduces our "accepting love." My view may not be typical or simple, but I argue that Christians should seriously consider adopting it.

My belief is driven by the principle of shalom. Shalom is a Hebrew word meaning "peace." Such peace is not just a lack of violence, but a genuine harmony both within one's self and with the world around him. It means wholeness. Shalom exists both on a physical and a metaphysical level. Shalom is what will be achieved in the new earth, which the Apostle John describes in Revelation 21.

Then I saw a new heaven and a new earth. The first heaven and the first earth had disappeared, and there was no sea anymore. And I saw the holy city, the New Jerusalem, coming down out of heaven from God. It was prepared like a bride dressed for her husband. And I heard a loud voice from the throne, saying, "Now God's presence is with people, and he will live with them, and they will be his people. God himself will be with them and will be their God. He will wipe away every tear from their eyes, and there will be no more death, sadness, crying, or pain, because all the old ways are gone (Rev 21:1-4 New Century Version).

In this new earth, it certainly seems that humanity would be rid of all imperfections and genetic disorders. In the new earth, there will be no human flaws. Though this new earth will not arrive before the coming of Christ, it makes sense for Christians to pursue it. "Thy Kingdom come, Thy 
will be done, on earth as it is in heaven" is not something for which we should have to wait (Flew, 1934). As the theologian Timothy Ngern points outs, the "church fulfills her calling best when she makes genuine differences in the contemporary world" (2013, p. 11). The best way to make these differences is in tangible places where suffering and injustice are most intense.

Shalom is not just accepting love, for that would neglect the physical part of peace and allow people to continue in suffering. If something can be done to alleviate suffering, then it should be done. On the other hand, shalom is not just transforming love, for that would be to deny the intrinsic value of humans. We must remember that man is made in the image of God, and therefore has value on that basis alone.

How does this relate to the bioethical issue of genetic engineering? I would contend that this view could be applied very practically. Ethicists should seek a balance between transforming and accepting love. Humanity should try to combat the fall while still celebrating the uniqueness of each human.

Wolpe's definition of obligatory versus non-obligatory services fits well with this view. We can practice transforming love by helping those who are sick and cannot function, and we can practice accepting love by helping our fellow man realize that he does not need to be perfect, or even above average, to make a worthy contribution to this world. We do not need to get so caught up in defining therapy versus enhancement, for these terms become easily definable when one simply has clarity of thought. Pursuing shalom, in its fullest sense, would keep genetic engineering on a straight and ethical path.

\section{References}

Anderson, W. F. (1985). Human gene therapy: scientific and ethical considerations. Journal of Medicine and Philosophy, 10(3), 275-292. doi:10.1093/jmp/10.3.275

Fischer, B. (2013). The search for perfection: Understanding the motives of Nazi experimentation. Tulane Journal of International Affairs, 1(2).

Flew, R. N. (1934). The idea of perfection in Christian theology. Oxford University Press.

Kass, L. (2003). Ageless bodies, happy souls. The New Atlantis, 1, 9-28.

Kimball, L. (2013, September 26). Evolution: Devilish gnostic system of self-perfection. Retrieved from http://patriotsandliberty.com/lindas-latest/2013/9/26/evolution- devilishgnostic-system-of-self-perfection

Litovsky, V. G., \& Dusek, J. B. (1985). Perceptions of child rearing and self-concept development during the early adolescent years. Journal of Youth and Adolescence, 14(5), 373-387. doi:10.1007/BF02138833 
Nettle, D. (2002). Height and reproductive success in a cohort of British men. Human Nature, 13(4), 473-491. doi:10.1007/s12110-002-1004-7

Ngern, T. L. T. (2013). Prophetic evangelicals: Envisioning a just and peaceable kingdom, edited by Bruce Ellis Benson, Malinda Elizabeth Berry and Peter Goodwin Heltzel (eds.). Reviews in Religion \& Theology, 20(1), 11-17.

Raniszewska-Wyrwa, A. (2012). Aesthetic surgery. Ethical aspects of non-therapeutic medical intrusions into human corporeality. Physiotherapy / Fizjoterapia, 20(1), 47-55.

Resnik, D. (1994). Debunking the slippery slope argument against human germ-line gene therapy. Journal of Medicine and Philosophy, 19(1), 23-40. doi:10.1093/jmp/19.1.23

Sandel, M. (2004). The case against perfection. The Atlantic Monthly, 293(3), 51-62.

Trachtman, H. (2005). A man is a man is a man. The American Journal of Bioethics, 5(3), 31-33. doi: $10.1080 / 15265160591002746$

Walters, L., \& Palmer, J. C. (1997). “The” Ethics of Human Gene Therapy. Oxford University Press, USA.

Wolpe, P. R. (2002). Treatment, enhancement, and the ethics of neurotherapeutics. Brain and cognition, 50(3), 387-395. doi:10.1016/S0278-2626(02)00534-1

Zanger, J. (1983). Speaking of the unspeakable: Hawthorne's "the birthmark". Modern Philology, 80(4), 364-371. doi: $10.1086 / 391243$

Zimmerman, B. K. (1991). Human germ-line therapy: The case for its development and use. Journal of medicine and philosophy, 16(6), 593-612. doi:10.1093/jmp/16.6.593 